\title{
A Meta-Analysis of Research on Technological Pedagogical Content Knowledge by Gender
}

\author{
Binnur Ergen \\ Mersin University, Turkey \\ ORCID: 0000-0002-9772-5758 \\ Tugba Yanpar Yelken \\ Mersin University, Turkey \\ ORCID: 0000-0002-0800-4802 \\ Sedat Kanadli \\ Mersin University, Turkey \\ ORCID: 0000-0002-0905-8677
}

\begin{abstract}
The purpose of this study is, by using meta-analysis method, to examine whether there is a significant difference in the effect size of the Technological Pedagogical Content Knowledge (TPACK) according to gender. For this purpose, it was examined whether both Technological Pedagogical Content Knowledge and the knowledge types related to TPACK shows a statistically significant difference by gender. A total of 29 studies conducted both in Turkey and abroad between 2007 and 2017 and meet the inclusion criteria were synthesized by the meta-analysis method. "Cohen's d" was chosen as the effect size index in order to examine the knowledge types related to TPACK by gender. Since the studies were obtained from the literature, primary studies were combined according to the Random Effects Model. It was concluded as a result of the analysis that there is a significant difference between the knowledge types about TPACK by gender, and in the sub-group analysis, technology knowledge, technological pedagogical knowledge and technological pedagogical content knowledge have a significant effect size in favor of male; on the other hand, content knowledge, pedagogical content knowledge, and technological content knowledge have an insignificant effect size in favor of male and pedagogical knowledge has an insignificant effect size in favor of female.
\end{abstract}

Keywords: Technological pedagogical content knowledge; Gender; Meta-analysis; Subgroup analysis

\section{Introduction}

In the world of 21st century which is called "information age" or "digital age", technological developments reflect upon the education as the technological innovations are integrated into all areas. Technological developments give a rapid acceleration to education. The technological developments in the education process as well as the pedagogical competency of teachers and the developments in their subject matter knowledge provide an important integrity. In this regard, the model called Technological Pedagogical Content Knowledge was developed as 
TPACK model by Koehler and Mishra (2005) based on Shulman's (1986) Pedagogical Content Knowledge model. In TPACK Model, technology has been integrated into teachers' knowledge, skills and competencies (Koehler \& Mishra, 2005). Kabakci-Yurdakul (2013) emphasized that, in Technological Pedagogical Content Knowledge Model, the teachers' subject matter knowledge, their pedagogical competency and technology use skills should be given in relation to each other rather than giving them as independent disciplines. When the three basic types of knowledge (pedagogy, subject matter and technology knowledge) are combined, technological pedagogical content knowledge (TPACK) is formed. According to Schmidt et al. (2009), technological pedagogical content knowledge is generally the integrated knowledge required to combine technology and teaching within a specific subject.

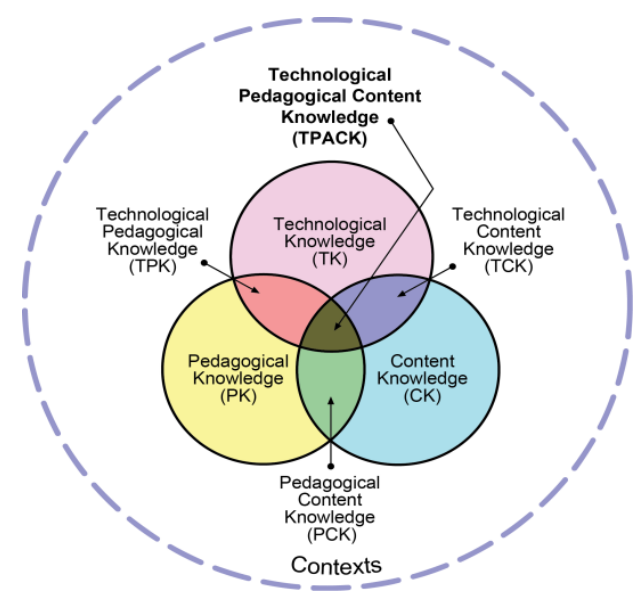

Figure 1. TPACK Model (www.tpack.org)

In order to better understand the TPACK model, first of all, content knowledge (CK), pedagogy knowledge (PK) and technology knowledge (TK) should be separately explained, and, as a consequence of bilateral combination, pedagogical content knowledge (PCK), technological pedagogical knowledge (TPK) and technological content knowledge (TCK) should be clarified.

Content knowledge (CK) means that teachers and teacher candidates know about the principles, rules, theories, etc. related to their subject matter (Yanpar-Yelken, Sancar-Tokmak, Ozgelen, \& Incikabi, 2013). For instance, a science teacher should know the necessary methods to convey the cell which is the smallest unit of living organism, the organelles within the cell and their tasks in the cell to the students. The knowledge of the science teacher about the cell refers to the content knowledge (CK). According to Koehler and Mishra (2008), pedagogical knowledge (PK) is a general form of knowledge that is applicable to the student's learning, classroom management, lesson planning development and implementation, and assessment of the student. Yanpar-Yelken (2012) states that pedagogical knowledge (PK) covers subjects such as learning, evaluation, development, implementation, planning, classroom management, organizing the classroom environment and in-class communication. Technology knowledge (TK) includes information and skills needed to use certain technologies. Besides, technology knowledge (TK) contains information about multimedia, PowerPoint, interactive whiteboards and advanced technologies such as internet, digital video (Jang \& Tsai, 2013).

Koehler and Mishra (2009), describe technological pedagogical knowledge (TPK) as the knowledge covering changes that can occur in learning and teaching in certain situations by using certain technologies. This involves the pedagogical advantages and disadvantages of 
various technological instruments since they are associated with disciplinary and developmentally pedagogical designs and strategies. According to Shulman (1986), pedagogical content knowledge (PCK) refers to content knowledge about teaching process. For example, a teacher should organize the classroom environment for the subject and the subject, bring out the pre-knowledge of the students with various teaching methods and be able to practice the instructional planning in the classroom. According to Schmidt et al. (2009), technological content knowledge (TCK) refers to the knowledge of how technology can create new explanations for specific content. Yanpar-Yelken (2012) explained that techno-pedagogical knowledge can be put into practice with some teaching methods. Teachers, for example, can make the teaching process active by increasing their interactions with students through using learning management systems such as educational social network sharing sites (Edmodo, Ning, etc.) and Moodle in the education process.

When we combine pedagogy, content and technology knowledge, technological pedagogical content knowledge (TPACK) is formed. Schmidt et al. (2009) underlined that technological pedagogical content knowledge is the integrated knowledge used to combine technology with teaching for a particular field. Technological Pedagogical Content Knowledge is a guide for determining the areas where development is needed for technology integration. The TPACK is of importance due to the fact that it brings together different variables that arise in the process of integration of technology, draws attention to the relations between them and, therefore, presents different dimensions as a whole which are included in the teacher training program and should be followed for technology integration (Akkoc et al., 2011). According to Mishra and Koehler (2006), TPACK framework is based on the planning of teaching activities in which teachers will use the technological pedagogical content knowledge in accordance with the constructivist approach (Yanpar-Yelken et al., 2013).

The literature review shows that there are descriptive (Acikgul \& Aslaner, 2015; Akgun, 2016; Cuhadar et al., 2013; Demir \& Firat-Durdukoca, 2018; Kula, 2015; Sancar-Tokmak, YavuzKonokman \& Yanpar-Yelken, 2013), relational (Alshehri, 2015; Canbolat, 2011; Holland, 2014; Millen, 2015; Wright, 2017) and experimental studies (Anderson, 2012; Canbazoglu-Bilici, 2012; Ceylan. et al, 2014; Depew, 2015; Price, 2013) in determining TPACK. It was most observed in these studies whether TPACK showed a significant difference by gender.

\section{TPACK and Gender}

Gender is a variable that is frequently studied in terms of education and is a disposition that does not change during the course of the study and also exists before the study. The frequent use of gender variable in educational science researches (Gliner et al., 2015) proves the importance of this variable. In general, there are many differences between male and female genders due to the cultural features of the society. For example, attitudes towards the use of information technology tools may vary in terms of gender. The society deems technology as highly technical and of male interest, and perceives the use of information technology tools as a male-specific activity (North \& Noyes, 2002). This perception appears to lead female to develop negative attitudes towards information technology tools (Sainz \& Saez, 2010). Since the use of information technology tools is an important skill for teachers' technological pedagogical content knowledge, gender may have an effect on TPACK competency of the teachers. Besides, the studies examining whether TPACK shows a significant difference by gender can give contradictory results. For example, in Kazu and Erten's (2014) study, while there is no significant difference in CK, TK, TCK, PCK and TPACK sub-dimensions according to 
gender, there is a significant difference in the sub-dimensions of PK and TPK in favor of female. Similarly, another study that showed a significant difference in favor of female is Wright and Akgunduz's (2018) study of TPACK by gender. In the study by Gundogmus (2012) which reached similar findings, there is no significant difference between male and female in the CK and PCK dimensions, although a significant difference in favor of male is seen in TK, PK, TPK and TPACK. In the study conducted by Canbolat (2011), a significant difference was found in favor of male in the sub-dimensions of TK, TPK, TCK and TPACK. Therefore, it is seen that there is a contradiction for gender variable in primary studies. A meta-analysis is needed to solve this contradiction.

In the Turkish literature, there is a meta-analysis study on this issue conducted by Tuncer and Dikmen (2018). In this meta-analysis study conducted with 6 master thesis studies, it was found that gender was not a dominant independent variable in terms of TPACK competencies. It is aimed in this meta-analysis study to solve the gender related contradiction by using the studies (master thesis/doctoral dissertation and article) published both in Turkish and international literature -different from the study of Tuncer and Dikmen (2018)- and to make suggestions for the studies to be carried out in this regard.

Thus, the purpose of the present study is to determine whether technological pedagogical content knowledge shows a significant difference in the effect size by gender. The following questions were sought for this purpose:

1. Does Technological Pedagogical Content Knowledge show a significant difference in terms of effect size by gender?

2. Do the sub-dimensions related to TPACK have a significant difference in terms of effect size by gender?

3. Does the effect of gender on TPACK practices differ significantly according to the place where the study was carried out, the research design, the type of the study and the type of scale used in the study?

\section{Methodology}

\section{Research Design}

Meta-analysis method was used in this study to calculate the overall effect size of the studies on TPACK in terms of gender. According to Glass (1976), meta-analysis is a statistical method used to combine the analysis results from primary studies. In addition, meta-analysis can be explained as the method of combining the results of multiple studies which are independent from each other and making statistical analysis of the findings obtained (Akgoz, Ercan, \& Kan, 2004). In short, meta-analysis is an analysis of the analyses (Cohen et al., 2000). Cooper (2010) explains the meta-analysis process in 7 stages: (i) formulating the problem; (ii) researching the literature; (iii) collecting information about the studies; (iv) evaluating the quality of the studies; (v) combining the results of the studies and analyzing them; (vi) interpreting the results of the analysis, (vii) reporting and presenting the results of the studies. Dincer (2014) defines meta-analysis as grouping the similar studies on a topic, a theme or a study area under similar criteria and interpreting the findings of these studies together. In this context, the meta-analysis method is of importance in that it enables to combine various studies in which TPACK is examined by gender and allows the overall effect to be calculated and interpreted. 


\section{Literature Review Procedures}

Google Scholar, Turkish CoHE (Council of Higher Education) National Thesis Center, ULAKBIM, Proquest, Scopus, Sciencedirect, Taylor \& Francis Online, Cabdirect, Proquest Dissertations and Theses Global, ERIC, EBSCO and SSCI databases were searched in order to reach all the studies carried out in Turkey and abroad about Technological Pedagogical Content Knowledge. The search process was conducted between March 2015 and January 2018 and the complementary search continued until July 2018. The keywords such as "technological knowledge", "pedagogical knowledge", "content knowledge", technological content knowledge", "pedagogical content knowledge", "technological pedagogical knowledge", " technological pedagogical content knowledge", "TK", "PK", "CK', "TPK", "TCK", "PCK", "TPCK", "TPACK", "TPACK and gender" "were searched in these databases. Reference sections of the studies related to the subject were examined and it was checked whether there were any studies that could not be reached. Access to necessary data was achieved by getting in contact with the authors of restricted access theses. In addition, the search process was carried out by two researchers who had studies in this field and the studies reached by the two researchers were crosschecked and the related studies were included. As a result of the search process, 482 studies conducted on Technological Pedagogical Content Knowledge both at domestic and abroad were accessed.

\section{Meta-Analysis Inclusion Criteria}

For a study carried out on Technological Pedagogical Content Knowledge to be included in this meta-analysis study, it must (i) be conducted between 2007-2017 in Turkey, (ii) employ a measurement tool similar to Sahin's (2011) TPACK Scale and score and interpret likewise, (iii) revealed whether TPACK shows a significant difference by gender, or (iv) report necessary quantitative data (sample size, mean, standard deviation, t-test and $p$ value) to calculate the effect size, and (v) use parametric statistical methods. According to Onwuegbuzie \& Levin (2002), the parametrical effect sizes are negatively affected since the scores in the primary studies do not show a normal distribution (cited by Leech \& Onwuegbuzie, 2002); therefore, they were not included in this meta-analysis study. The studies employing the scales of which validity and reliability were not reported and using non-parametric tests were also not included in this meta-analysis study.

A total of 482 studies were examined. As a result of the review, there remained 68 studies to be included in this study when excluding the studies which are not based on Technological Pedagogical Content Knowledge proposed by Koehler and Mishra (2005), do not examine the 7 knowledge dimensions of TPACK, and analyze the variables other than gender. Of the 68 studies, some were not included in the meta-analysis as 6 of them do not have the necessary data to calculate the effect size, the 24 used non-parametric tests, the 7 employed a scale which is scored different, and the 3 had a restricted access and the permission could not be taken from their authors. As a result, 29 studies carried out about the effect of TPACK on gender were included in the meta-analysis. In the subgroup analysis, because the scales of 4 studies were different from each other, 25 studies were used to calculate the results. Flow chart for the inclusion process of the studies is seen in Figure 2. 


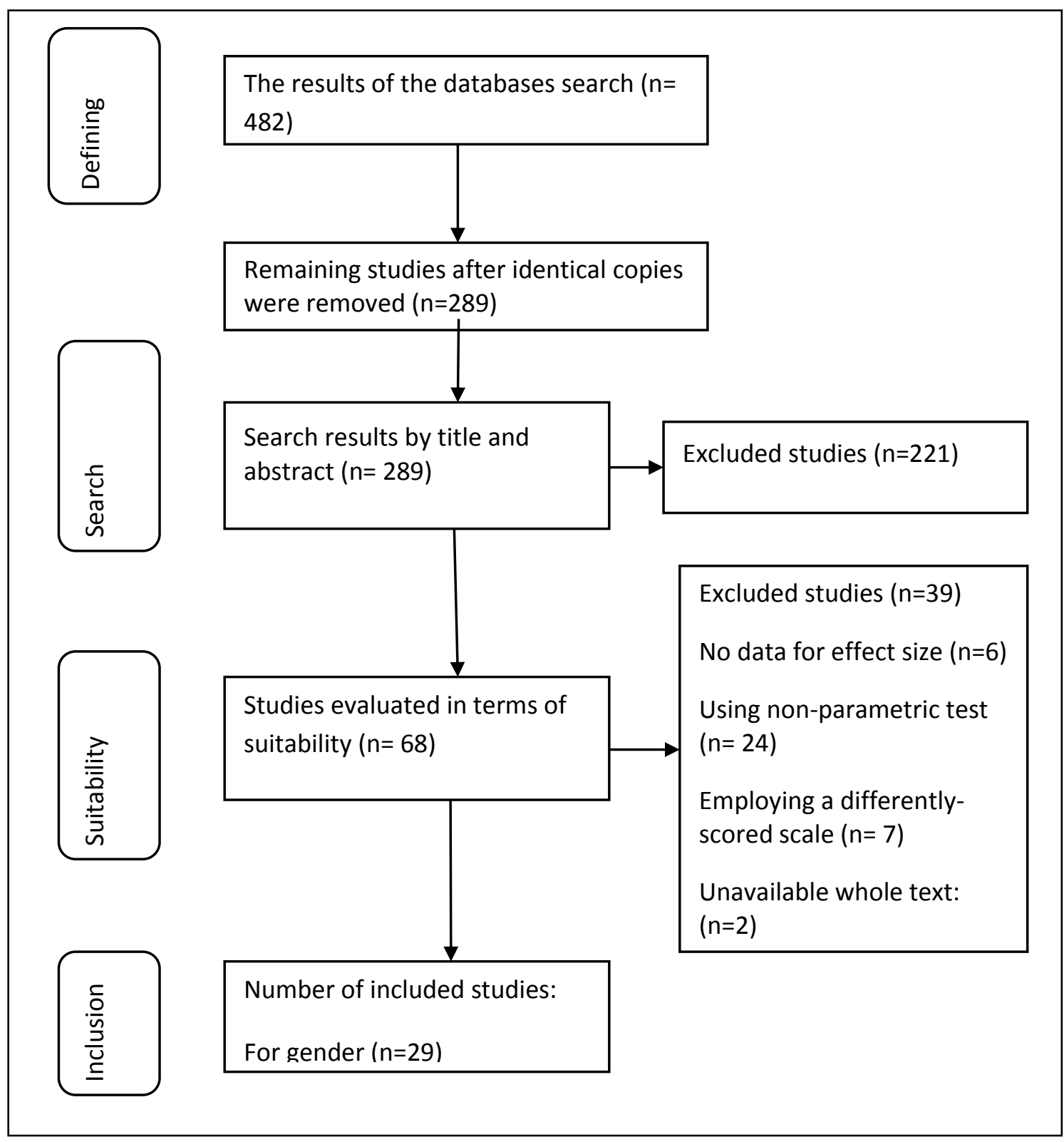

Figure 2. Flowchart for the Inclusion Process

\section{Coding of the Studies}

The studies included in this meta-analysis study were coded in four categories: (i) the research report, (ii) the research designs, (iii) the measurement of the variables and (iv) the data necessary for the effect sizes.

\section{(i) Characteristics of the Research}

The surnames of the authors of the study, the publication date of the study and the type of the study were coded in this category. The type of the study was classified as article and thesis. Theses transformed into an article were coded as an article. The variable was classified only as gender. 


\section{(ii) Research Designs}

In this category, the experimental and relational studies which examined whether the technological pedagogical content knowledge sub-dimensions significantly differ by gender were coded.

\section{(iii) Measurement of the Variables}

Types of information related to technological pedagogical content knowledge and measurement tools used in gender measurement were coded in this category. The literature review shows that various scales were used in the measurement of Technological Pedagogical Content. In the studies included in the study, the scale, developed by Schmidt et al. (2009), which is of 5-point Likert-type and consists of 47-item measuring TK, CK, PK, PCK, TPK, TCK and TPACK dimensions of teacher candidates was taken into consideration. Sahin (2011) also developed a 7-dimension, 47-item and 5-point Likert-type scale according to TPACK model to identify the knowledge dimensions (TK, PK, CK, TPK, TCK, PCK and TPACK) about technological pedagogical content knowledge. Since the scale by Sahin (2011) was the most used TPACK scale in the studies included in this study, it was taken into account. In addition, Pamuk et al. (2012) developed a "Technological Pedagogical Content Knowledge" scale consisting of 10point Likert type, 4 sub-dimensions and 15 items in order to examine the integration of teachers' information and communication technologies into learning-teaching process (TK, TPK). Ozturk and Horzum (2011) adapted the "Technological Pedagogical Content Knowledge' scale developed by Schmidt et al. (2009) into Turkish. The scale consists of 47 items and 7 factors. Another adaptation of "Technological Pedagogical Content Knowledge" scale by Schmidt et al. (2009) into Turkish was conducted by Kaya and Dag (2013) for classroom teachers.

\section{(iv) Data Necessary for the Effect Size}

The mean, standard deviation and sample sizes of both male and female were coded as a result of t-test in order to determine whether Technological Pedagogical Content Knowledge shows a significant difference by gender. In the researches which do not provide this information, the standard difference of the mean, standard error and sample size were coded.

\section{Intercoder Reliability}

According to Lipsey and Wilson (2001), it is recommended to code 20 or more studies for a consistent estimate of reliability among coders. Therefore, to determine the reliability of the coding, 20 studies were randomly selected from the studies included in the meta-analysis and the two coders were requested to code the data in the coding form. Agreement rate among coders is calculated by dividing the number of agreed studies by the total number of studies (Card, 2012). When the agreement rate is greater than $80 \%$, coding reliability is ensured (Miles \& Huberman, 1994). The agreement rate in this study was calculated as $95 \%$ according to the data of the coders who made the evaluation, which proves the coder reliability.

\section{Data Analysis Strategies}

"Cohen's d" was chosen as the effect size index to analyze the subdimensions of TPACK according to gender. Cohen's $d$ refers to the difference between the two groups mean in terms 
of general standard deviation and is more appropriate for samples larger than 20 (Cooper, 2010). This index is interpreted as "low" effect at 0.20, "medium" effect at 0.50 and "high" effect at 0.80 (Cohen, 1988). In this study, $d$ index was interpreted as "low" between 0.000.20 , "medium" between 0.21-0.50, "high" between 0.51-0.80 and "very high" if greater than 0.81 .

In the meta-analysis method, after calculating the effect sizes of individual studies, these effect sizes are combined and the overall effect size is calculated according to the Fixed or Random Effects Model. Although it is determined which model to be applied by heterogeneity test, it is recommended to use the Random Effects Model if individual studies are obtained from the literature (Borenstein et al., 2013). For this reason, combining effect sizes in this study was performed according to Random Effects Model. However, heterogeneity test was applied to determine the presence and magnitude of heterogeneity among studies. This test examines whether the variance $(Q)$ between the effect sizes of the studies is due to the sampling error $\left(X^{2}\right)$ (Cooper, 2010). Card (2012) emphasizes that the $Q$ value calculated with a certain degree of freedom should be determined, at $95 \%$ confidence level, as "homogeneous" if it is lower than $\chi^{2}$ value at the same degree of freedom, "heterogeneous" if it is higher than $\chi^{2}$ value.

Though Q statistic shows the heterogeneity of the studies, it does not refer to the level of heterogeneity (Card, 2012), therefore, $\mathrm{I}^{2}$ coefficient is used. Borenstein (2013) states that the $\mathrm{I}^{2}$ coefficient provides an interpretation on the amount of variance in the relational measurements. Bakioglu and Ozcan (2016) express that the $\mathrm{I}^{2}$ coefficient indicates the percentage of variability of the effect size estimates due to heterogeneity rather than sampling error. The $\mathrm{I}^{2}$ coefficient is interpreted as "low" heterogeneity up to $25 \%$, "medium" heterogeneity up to $50 \%$ and "high" heterogeneity up to $75 \%$ (Higgins et al., 2003).

Subgroups Analysis was performed to determine whether the overall effect size calculated for gender was significantly different according to the sub-dimensions of the scales. However, in order to determine this, all scales should be composed of the same sub-dimensions. For this reason, to ensure this, the most used scale was chosen in the studies included in the metaanalysis. This scale is a 47-item, 5-point Likert-type scale developed by Sahin (2011) to determine the knowledge dimensions (TK, PK, CK, TPK, TCK, PCK, TPACK) of teacher candidates consisting of 7 sub-dimensions according to TPACK model. In the studies included in the metaanalysis, the funnel plot and the Egger's Intersection Test were used to determine whether there is publication bias and the effect of this bias on the results obtained. Office programs, CMA 2.0 software and R metaphor (Viechtbauer, 2017) packaged software were used in the implementation of the meta-analysis.

\section{Findings}

The total sample size of the studies included in this study is 9562 people, including 154 instructors, 2705 teachers, and 4797 teacher candidates. In this sample group, there are 5320 female and 4242 male. The distribution of the studies according to the type of study, research design, sample group, gender and scale is given in Table 1.

As seen in Table 1, 48.28\% ( $\mathrm{f}=14)$ of the studies included in this meta-analysis are the article while $51.72 \%(f=15)$ are the thesis. $82.76 \%(f=24)$ of these studies employed experimental design while $17.24 \%(f=5)$ used relational design. $2.01 \%(f=154)$ of the individual studies were conducted with instructors, $62.66 \%(f=4797)$ with teacher candidates and $35.33 \%(f=2705)$ 
with teachers. A TPACK scale adapted by Sahin (2011) was used in $48.27 \%$ of the studies ( $f=14$ ) while the scale adapted by Bahcekapili (2011) was applied in 3.45\% ( $f=1)$, Pamuk et al. (2012) in $10.34 \%$ ( $f=3)$, Ozturk and Horzum (2011) in 10.34\% ( $f=3)$, Kaya and Dag (2013) in 6.90\% ( $f=2)$, Kaya, Kaya and Emre (2013) in 3.45\% ( $f=1)$, and a scale developed by Bostancioglu (2014) in $3.45 \%(f=1)$, a TPACK Efficacy scale by Kabakci-Yurdakul (2011) in $3.45 \%(f=1)$, and lastly, the TPACK scale by Schmidt et al. (2009) in 10.34\% ( $f=3)$.

Table 1. Frequency and Percentages of the Studies according to Type of Study, Research Design, Sampling Group Type, Gender and TPACK Scale.

\begin{tabular}{lll}
\hline Variable & Frequency (N) & Percentage (\%) \\
\hline Type of Study & 14 & \\
\hline Article & 15 & 48.28 \\
\hline Thesis & & 51.72 \\
\hline Research Design & 24 & 82.76 \\
\hline Experimental & 5 & 17.24 \\
\hline Relational & & \\
\hline Sample Group & 154 & 2.010 \\
\hline Instructors & 2705 & 35.33 \\
\hline Teachers & 4797 & 62.66 \\
\hline Teacher candidates & & \\
\hline Gender & 4441 & 56.91 \\
\hline Female & 3362 & 43.09 \\
\hline Male & & \\
\hline Scale & 3 & 10.34 \\
\hline Schmidt (2009) & 14 & 48.27 \\
\hline Sahin (2011) & 3 & 10.34 \\
\hline Pamuk et al. (2012) & 2 & 6.900 \\
\hline Kaya and Dag (2013) & 1 & 3.450 \\
\hline Bostancioglu (2014) & 1 & 3.450 \\
\hline Kaya, Kaya, and Emre (2013) & 3 & 10.34 \\
\hline Ozturk and Horzum (2011) & 1 & 3.450 \\
\hline Kabakci-Yurdakul (2012) & 1 & \\
\hline Bahcekapili (2011) & & \\
\hline & & \\
\hline
\end{tabular}

\section{Findings Related to Gender Variable}

In order to determine whether TPACK shows a significant difference according to gender, the forest plot for the effect sizes is given in Figure-3.

As seen in the forest plot, 29 studies included in the meta-analysis and 29 effect sizes are given. $72.41 \%(f=21)$ of the calculated effect sizes are in favor of males and $27.59 \%(f=8)$ in favor of females. $48.28 \%(f=14)$ of the effect sizes were found significant at 0.05 confidence level while $51.72 \%$ ( $f=15)$ were not. According to the effect size category adopted in this study, $17.24 \%(f=5)$ are "low", 17.24\% $(f=5)$ "medium", 3.45\% ( $f=1)$ "high" and $62.07 \%(f=18)$ "very high". 
Study Name



Figure 3. Forest Plot for Gender Variable

Since primary studies were obtained from the literature, the overall effect size was accepted under the Random Effects Model. According to this model, the overall effect size (Cohen's d) was calculated as $-0.059(-0.111,-0.007)$. As seen in the forest plot, this value is in the "insignificant" range in favor of male; however, it is a significant $(p<.05)$ effect size. Accordingly, it can be said that the total score of male on TPACK scale is higher than that of female. The subgroup analysis was performed to determine whether the calculated overall effect size differed significantly in the TPACK sub-dimensions (TK, PK, CK, TCK, TPK, PCK). 4 studies consisting of different sub-factors were excluded from this analysis. Subgroup analysis results are given in Table 2.

Table 2. Subgroup Analysis Results

\begin{tabular}{|c|c|c|c|c|c|c|c|c|}
\hline Subgroup & $\mathrm{k}$ & Effect Size & $95 \% \mathrm{Cl}$. & & & teroge & neit & \\
\hline & & & Lower Limit & Upper Limit & $p$ & $\mathrm{Qb}$ & $\mathrm{d} f$ & $p$ \\
\hline TPACK Subdimensions & 158 & & & & & 44.25 & 6 & 0.000 \\
\hline CK & 23 & -0.042 & -0.118 & 0.034 & 0.276 & & & \\
\hline PK & 21 & 0.040 & -0.042 & 0.122 & 0,338 & & & \\
\hline TK & 25 & -0.337 & -0.432 & -0.242 & 0.000 & & & \\
\hline PCK & 23 & -0.009 & -0.084 & 0.066 & 0.815 & & & \\
\hline TPK & 22 & -0.139 & -0.222 & -0.056 & 0.001 & & & \\
\hline TCK & 21 & -0.143 & -0.244 & -0.042 & 0.006 & & & \\
\hline TPACK & 23 & -0.113 & -0.199 & -0.027 & 0.010 & & & \\
\hline
\end{tabular}

As seen in Table 2, according to heterogeneity test, $Q_{b}$ value was found 44.25 at 6 degrees of freedom, and the significant $Q_{b}$ value $\left(Q_{b}>\chi^{2} ; p<.05\right)$ shows a significant difference in the overall effect size calculated between the knowledge types of TPACK. It is seen, when each 
type of information is examined, that technology knowledge, technological pedagogical knowledge and technological pedagogical content knowledge have a significant effect size $(p<0.05)$ in favor of males; on the other hand, content knowledge, pedagogical content knowledge, technological content knowledge and pedagogical knowledge were found to have no significant effect size.

Heterogeneity test about gender was conducted to determine whether there is heterogeneity among the studies included in the meta-analysis, and if any, its size. The result of this heterogeneity test is given in Table 3.

Table 3. Heterogeneity Test Results about Gender

\begin{tabular}{lccccccccc}
\hline Model & N & ES & SE & \multicolumn{9}{c}{$95 \% \mathrm{Cl}$} & Heterogeneity \\
& & & & Lower Limit & Upper Limit & Q & df & p $\left.\right|^{2}$ \\
\hline Fixed Effect & 29 & -0.052 & 0.009 & -0.071 & -0.032 & 168.94 & 28 & 0 & 83.43 \\
\hline Random Effect & 29 & -0.059 & 0.025 & -0.111 & -0.007 & & & \\
\hline
\end{tabular}

As seen in Table 3, heterogeneity test was found significant $(p<.05)$. Q value is 168.940 with 28 degrees of freedom. The critical value in chi-square table, with 28 degrees of freedom and at .05 level, is about 41,337 . Therefore, since the $Q$ value is greater than the critical value, it can be said that the variance between the studies is due to the characteristics of the studies rather than sampling error. The $\mathrm{I}^{2}$ index proves with a value of $84 \%$ that the heterogeneity between studies is very high. Moderator analysis was performed to determine the possible causes of this heterogeneity between studies.

\section{Moderator Analysis}

The probable moderators to explain the heterogeneity of the Technological Pedagogical Content Knowledge by gender were determined as the research place, the research design, the type of the study and the type of scale used in the study. In the moderator analysis, the research place was grouped as domestic and international, the research design was grouped as experimental and relational, and the study type was grouped as article and thesis. The TPACK scales by Schmidt (2009), Sahin (2011), Ozturk and Horzum (2011), Pamuk et al. (2012) and Kaya and Dag (2013) are the most commonly used scales in the studies. The scales used in only one study were not included in the moderator analysis. The results are given in Table 4.

Table 4. Moderator Analysis Results






\begin{tabular}{|c|c|c|c|c|c|c|c|c|}
\hline 3.Type of Study & & & & & & 15.107 & 1 & 0.000 \\
\hline Article & 14 & -0.013 & -0.040 & 0.015 & 0.376 & & & \\
\hline Thesis & 15 & -0.090 & -0.117 & -0.062 & 0.000 & & & \\
\hline 4.Scale & & & & & & 9.168 & 1 & 0.057 \\
\hline Schmidt (2009) & 3 & -0.155 & -0.240 & -0.070 & 0.000 & & & \\
\hline Sahin (2011) & 14 & -0.080 & -0.104 & -0.057 & 0.000 & & & \\
\hline $\begin{array}{l}\text { Ozturk and Horzum } \\
(2011)\end{array}$ & 3 & -0.009 & -0.089 & 0.071 & 0.825 & & & \\
\hline Pamuk et al. (2012) & 3 & -0.037 & -0.171 & 0.098 & 0.592 & & & \\
\hline Kaya and Dag (2013) & 2 & -0.016 & -0.087 & 0.054 & 0.646 & & & \\
\hline
\end{tabular}

As seen in Table 4, there is a significant difference in effect size since the p-value of the research place of studies (domestic-abroad) is less than 0.05 . $Q_{b}$ value was calculated as 9.358 with 1 degree of freedom, which is significant $(p<.05)$. This result shows that the research place is a significant moderator, in other words, it contributes to the heterogeneity between the studies. The effect size of international studies is 0.197 in favor of males and the effect size of domestic studies is 0.045 in favor of males. According to this result, in the international studies, male participants scored higher in terms of TPACK than female participants.

The research design is categorized as relational and experimental in the table and the $Q_{b}$ value is 0.349 , df value is 1 and $p$-value is 0.555 . The research design is not a significant moderator according to this result.

When the type of study is examined, it is seen that $Q_{b}$ value is $15.107, d f 1, p$-value is 0.000 . According to this result, the type of study is a significant moderator contributing to heterogeneity. The effect size of the articles is 0.013 in favor of males and the effect size of the thesis studies is 0.090 in favor of males. This result shows that male participants have higher scores on TPACK than female participants in the thesis studies.

According to the analysis results of the scales that meet the research criteria, the $Q_{b}$ value is $9.168 \mathrm{df}$ is 4 and $p$-value is 0.057 . According to this result, the type of scale is not a significant moderator contributing to heterogeneity. When the scales used in the primary studies were examined in terms of effect size, the scales developed by Schmidt (2009) and Sahin (2011) and the scales adapted by Ozturk and Horzum (2011), Pamuk et al., (2012) and Kaya and Dag (2013) showed a significant difference in effect size in favor of male. This result shows that, in the studies using the scales developed by Schmidt (2009) and Sahin (2011), the male participants scored higher on TPACK than female participants.

\section{Publication Bias}

In order to determine whether the overall effect size calculated for gender is due to publication bias, firstly, the funnel plot was examined. The funnel plot shows that there is no publication bias in the studies with the symmetrical distribution around the overall effect size (Borenstein et al., 2013). 


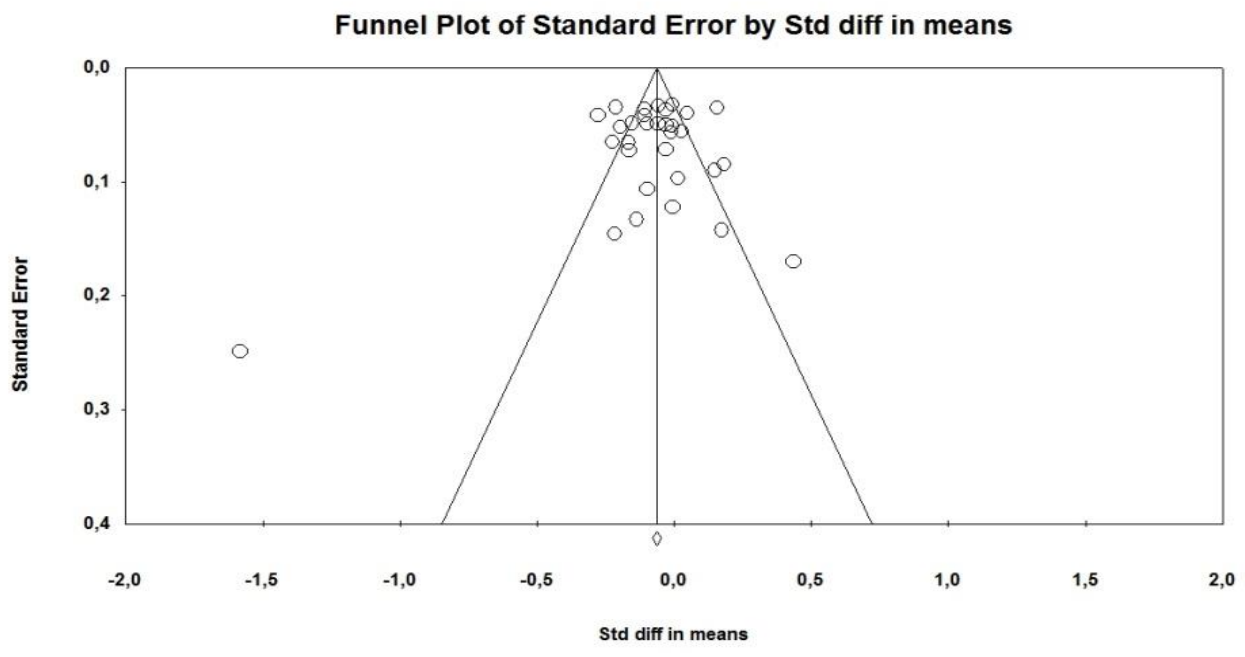

Figure 4. Funnel Plot for Gender Variable

According to Figure 4, the effect sizes calculated for gender are around the overall effect size and approximately symmetric. This indicates that there is no publication bias for the gender variable. However, since the interpretation of this plot is subjective (Borenstein et al., 2013), the Egger's Intersection Test of the tests used to determine the bias more accurately was applied. The Egger's Intersection Test is used to determine whether the asymmetry in the funnel plot is significant. The intersection value calculated with this test is expected to be zero; however, if this value is significantly different from zero, this refers to a publication bias (Card, 2012). The result of the Egger's Intercept test, which was conducted to more precisely determine the existence of publication bias, is given in Table- 5 .

Table 5. Egger's Intersection Test Results for Gender

\begin{tabular}{|c|c|c|c|c|c|c|c|}
\hline Variable & Intersection value(Bo) & Standard Error & $\begin{array}{l}\text { Lower } \\
\text { Limit }\end{array}$ & $\begin{array}{l}\text { Upper } \\
\text { Limit }\end{array}$ & t-value & $\mathrm{d} f$ & $\mathrm{p}$-two tailed \\
\hline Gender & -0.76339 & 1.10291 & -3.02638 & 1.4996 & 0.6922 & 27 & 0.49475 \\
\hline
\end{tabular}

As seen in Table 5, the intersection value $\left(B_{0}\right)$ was calculated as -0.76339 for gender. When the significance levels of the intersection values calculated for these variables are examined, it is observed that they are not significant in the $95 \%$ confidence interval ( $p>.05)$. According to the results, it can be said that there is no publication bias.

\section{Discussion and Conclusion}

In this meta-analysis study to determine whether the Technological Pedagogical Content Knowledge shows a significant difference by gender and to solve this conflict in the literature, 29 studies and 29 effect sizes that meet the inclusion criteria were identified. These effect sizes were combined according to the Random Effects Model. According to the Random Effects Model, lower limit of the overall effect size was calculated as -0.127 and the upper limit as 0.027 and -0.077 as a result of the combination of the effect sizes. The $Z$ test which tests the hypothesis that "effect size is zero" was found to be significant $(p<.05)$ since there is no " 0 " effect size between the lower and upper limits. The fact that effect size is negative means that 
it is in favor of male. These results show that the total score of male on TPACK scale is higher than that of female. Although there is no meta-analysis study in the international literature to compare with this finding, it was revealed in the meta-analysis study conducted by Tuncer and Dikmen (2018) in Turkish literature that gender is not a dominant independent variable in terms of TPACK competencies. Similarly, in the study by Unlu, Kaskaya, and Coskun (2017), which is one of the primary studies on technological pedagogical content knowledge by gender, no significant difference was found by gender variable when technology pedagogy and content knowledge dimensions of social studies teacher candidates were examined. One of the primary studies that showed a significant difference in terms of gender in the literature is the one conducted with 329 teacher candidates by Akyildiz and Altun (2018), which found that female teacher candidates are better at the dimensions of pedagogical knowledge, pedagogical content knowledge, technological pedagogical knowledge and technological pedagogical content knowledge than male teacher candidates. It was revealed in the study by Karadeniz and Vatanartiran (2015), which shows similarity in terms of gender variable, that teachers' only technology knowledge of TPACK factors differed significantly by gender showing that male teachers' perceptions of technology knowledge were higher than female teachers.

In most of the primary studies, a significant difference was found in favor of men. Considering that education has an important role in maintaining the life of the individual, selfdevelopment, being a member of the society and meeting the requirements of living in harmony with the society (Ozaydinlik, 2014), it is of essence that each individual has the right and the need to be educated. In all other countries as in Turkey, the boys are given more opportunities since gender inequality and sexist attitudes reign in using the right to education. Therefore, the female who are disadvantaged may have difficulties in accessing sufficient information in education and technology that is intertwined with education. As seen in most studies, TPACK levels of males differ significantly from females. In this regard, gender apartheid should be eradicated in the society and gender equality in education should be ensured. It is also to be ensured that girls have an active role from preschool to higher education, and then, in work life.

Heterogeneity test was performed in order to determine the heterogeneity and the size of heterogeneity of the studies included in the meta-analysis. As a result of this test, there was a significant heterogeneity between studies $\left(Q>\chi^{2} ; p<.05\right)$ and this heterogeneity was found to be "very high" $\left(I^{2}=84\right)$. This result shows that the variance is not only due to sampling error but also to the characteristics of the studies. It is necessary in this case to determine the variables contributing to the variance and to test whether there is a significant moderator. For this reason, the moderator analysis was conducted according to the research place, the research design, the type of study, the type of scale and the sub-dimensions of TPACK.

As a result of the categorical moderator analysis, the effect size of the studies conducted abroad and in Turkey was calculated according to the place where the studies were carried out. According to these results, the overall effect size of the studies conducted abroad is higher than domestic studies and a significant difference was found in favor of male. This may be due to the fact that the male participants abroad have an early education about technology and higher socio-economic conditions and more easily access to the technological equipment.

Another result of the categorical moderator analysis is in relation to the research design and the effect size of the studies in experimental design and relational design was calculated. However, since there is no significant difference between these effect sizes, the research 
design is not a significant moderator. This may due to the fact that the researchers collected the descriptive data about the participants through scales, regardless of research design.

The analysis of the studies according to the type of study was also done in the categorical moderator analysis. When the studies included in the meta-analysis were examined according to the type of study, the effect size of the articles was calculated. Since there is a significant difference between these effect sizes, the type of the study is a significant moderator. It was concluded that the thesis studies are more effective than the articles. The reason for this may stem from an extensive study in terms of the number of samples of the theses, the literature review, methods, and so on. As a result, it was revealed in thesis studies that male participants got higher scores in terms of TPACK than female participants.

Another result of categorical moderator analysis is related to the type of scale. It was found that the type of scale used in primary studies was not a significant moderator contributing to heterogeneity. When, according to this result, the scales used in primary studies were examined in terms of effect size, the scales developed by Schmidt (2009) and Sahin (2011) and the ones adapted by Ozturk and Horzum (2011), Pamuk et al., (2012), Kaya and Dag (2013) gave a significant effect size in favor of male participants. This result shows that the male participants in the studies using the scales developed by Schmidt (2009) and Sahin (2011) scored higher in terms of TPACK than female participants. This may be arising from the fact that applying these scales to the teachers who are more experienced in their profession and to a wider target may have increased the validity and reliability coefficient of the scale and provided a more significant result.

Sub-group analysis was performed to determine whether the gender-related differences result from the sub-dimensions of TPACK (TK, CK, PK, TPK, TCK, PCK, TPACK) and overall effect size differed significantly according to sub-dimensions. In order to perform the subgroup analysis, the studies included in the meta-analysis should be obtained with a similar type of scale. Therefore, the 25 studies gathering data with the scales developed to examine 7 subdimensions of TPACK were included in the meta-analysis. As a result of the subgroup analysis, there is a significant difference between the sub-groups in terms of effect sizes $\left(Q_{b}>\chi^{2} ; p\right.$ $<0.05)$. When each knowledge dimension is examined, it is seen that technology knowledge, technological content knowledge, technological pedagogical knowledge and technological pedagogical content knowledge are in favor of male but insignificant ( $p>0.05)$, and content knowledge and pedagogical content knowledge is significant $(p<0.05)$ in favor of male while pedagogical knowledge is significant in favor of female $(p<0.05)$. In the light of these findings, it is necessary that female's content knowledge, technology knowledge, technological content knowledge, technological pedagogical knowledge and technological pedagogical content knowledge be further developed.

\section{Limitations and Recommendations}

It was found in the literature review that types of knowledge related to TPACK have been most studied in terms of gender variable. Therefore, it was examined and interpreted this study only whether the TPACK and TPACK-related knowledge types of the participants differ by gender. However, (i) the participants' level of Technological Pedagogical Content Knowledge can also be investigated according to different variables. For example, the scope of the research can be extended considering demographic variables such as participants' age, education level, branch, seniority year and socio-economic status. (ii) The parametrical data of the participants' self- 
efficacy levels related to the Technological Pedagogical Content Knowledge may also be combined in accordance with the meta-analysis method and a general interpretation can be made for the results. (iii) The suitability of the studies on the participants' self-efficacy about the Technological Pedagogical Content Knowledge to the meta-analysis method can be combined and a general picture can be presented according to the results. TPACK competencies can be identified according to the participants' demographic variables such as gender, age, seniority and branch, and a meta-analysis study can be conducted. (iv) The suitability of the studies on the participants' self-confidence about the Technological Pedagogical Content Knowledge to the meta-analysis method can be combined and a general evaluation can be made about the results. TPACK self-confidence can also be determined according to the participants' demographic variables such as gender, age, seniority and branch. (v) The studies included in this meta-analysis were carried out mostly in the experimental design and partly the relational design, which is among the limitations of the study. What is more, experimental studies were studied as semi-experimental and weak experimental. It is advisable for researchers to carry out true experimental studies on the subject in order to ensure the reliability of true experimental studies. (vi) The study is limited by research articles and theses, but the scope of study can be extended by including papers. In addition, the study is limited with the years 2007-2017 and these limits can be broadened. (vii) Considering the content validity of the scales used in the studies and also the rapid advancement of technology and their contribution to education with an enormous acceleration, a more comprehensive and developed original scale for TPACK applications can be created by researchers. (viii) In accordance with the findings, especially female teachers and female teacher candidates should be given the importance of using technology through in-service trainings by integrating technology into education. To this end, they should be enabled to recognize and understand the technological tools they can use in educational environments, and thus, to increase the efficiency of participation. (ix) $1.61 \%$ of participants in the sample of the study were instructors, $48.22 \%$ were the teachers and $50.17 \%$ were the teacher candidates. Based on this result, further research should give importance to increase the ratio of academicians whose participation is low in this area and to examine their TPACK levels for they train teachers.

\section{References}

$\left({ }^{*}\right)$ marked studies were included in the meta-summary.

Acikgul, K. \& Aslaner, R. (2015). Ilkogretim matematik ogretmen adaylarinin TPAB guven algilarinin incelenmesi. Erzincan Universitesi Egitim Fakultesi Dergisi, 17(1), 118-152. DOI: http://dx.doi.org/10.17556/jef.04990

Akgoz, S., Ercan, I. Kan, I., (2004). Meta analiz. Uludag Universitesi Tip Fakultesi Dergisi, 30(2), 107-112.

Akkoc, H., Ozmantar, M.F., Bingolbali, E., Demir,S., Basturk, S., \& Yavuz, I. (2011). Matematik ogretmen adaylarina teknolojiye yonelik pedagojik alan bilgisi kazandirma amacli program gelistirme. TUBITAK Proje No: 107K531. Istanbul.

*Aksin, A. (2014). Sosyal bilgiler ogretmenlerinin teknolojik pedagojik alan bilgisi (TPACK) yeterlilikleri: Amasya ili ornegi) (Yayınlanmamis doktora tezi). Ataturk Universitesi Egitim Bilimleri Enstitusu. Erzurum, Turkiye.

Akyildiz, S. Altun, T. (2018). Sinif ogretmeni adayteknolojik pedagojik alan bilgilerinin (TPAB) bazi degiskenlere gore incelenmesi. Trakya Universitesi Egitim Fakultesi Dergisi, 8(2), 318-333. DOI: 10.24315/trkefd.322749 
*Alazcioglu, H. (2016). Ogretmen adaylarinin TPAB yeterlik duzeyleri ile Web 2.0 aracarini kullanim durumlari arasindaki iliskinin incelenmesi (Yayinlanmamis yuksek lisans tezi). Mevlana Universitesi Fen Bilimleri Enstitusu. Konya, Turkiye.

Alshehri, K. A. (2012). The influence of mathematics teachers' knowledge in technology, pedagogy and content (TPACK) on their teaching effectiveness in Saudi public schools (Unpublished doctoral dissertation). University of Kansas, Lawrence, KS.

*Altun, T. (2013). Examination of classroom teachers' technological pedagogical and content knowledge on the basis of their demographic profiles. Croatian Journal of Education, 15(2), 365-397.

Anderson, B. (2012). Testing the effectiveness of professional development for integrating technology in an Urban lowa Middle School (Unpublished doctoral dissertation). Northcentral University. Scottsdale, AZ.

*Avci, T. (2014). Fen bilimleri ogretmenlerinin teknolojik pedagojik alan bilgisi ve oz-guven duzeylerinin belirlenmesi (Yayinlanmamis yuksek lisans tezi). Celal Bayar Universitesi Fen Bilimleri Enstitusu. Manisa, Turkiye.

*Bagriyanik, K. E. (2015). Fen bilgisi ogretmen adaylarinin teknolojik pedagojik alan bilgilerine yonelik oz-yeterlik inanislari, tutumlari ve algilari (Yayinlanmamis yuksek lisans tezi). Cumhuriyet Universitesi Egitim Bilimleri Enstitusu. Sivas, Turkiye.

Bakioglu, A. \& Ozcan, S. (2016). Meta analiz. Ankara: Nobel.

Balcin, M. D., Ergun, A. (2016). Fen bilgisi ogretmen adaylarinin materyal gelistirme konusundaki teknolojik pedagojik alan bilgisi oz-yeterlik olcegi: Gelistirme, guvenirlik ve gecerlik calısmasi. Turkish Journal of Education, 5(3), 109-120.

Baran, E. Canbazoglu Bilici, S. (2015). Teknolojik pedagojik alan bilgisi (TPAB) uzerine alanyazin incelemesi: Turkiye Ornegi. Hacettepe University Journal of Education, 30(1), 15-32.

*Baturay, M.H., Gokcearslan, S., Sahin, S. (2017). Associations among teachers' attitudes towards computer-assisted education and TPACK competencies. Informatics in Education, 16(1), 1-23. DOI: 10.15388/infedu.2017.01

Bavonese, J. (2014). Determining the impact of a multiliteracies workshop on TPACK knowledge of elemantary preservice teachers (Unpublished doctoral dissertation). Alabama University. Tuscaloosa, AL.

*Bilici, S. (2015). Ortaogretim ogretmenlerinin teknolojik pedagojik alan bilgisi duzeylerinin etkilesimli tahta ve diger ogretim teknolojilerinin kullanma durumlarina gore incelenmesi (Yayinlanmamis yuksek lisans tezi). Yuzuncu Yil Universitesi Egitim Bilimleri Enstitusu Van, Turkiye.

Borenstein, M., Hedges, L.V., Higgins, J.P.T. \& Rothstein, H.R. (2013). Meta-analize giris. (Trans. Ed: S. Dincer). Ankara: Ani.

Bostancioglu, A. (2014). EFL-TPACK: The development of a questionnaire to measure the technology pedagogy and content knowledge of English as foreign language (EFL) teachers. The EUROCALL Teacher Ed SIG. Retrieved on 14 November 2018 from https://sites.google.com/site/teacheredsignice/programme/abstracts/efltpackquestionnaireforteachers. 
*Cam, E. (2017). Ilkogretim ogretmenlerinin teknolojik pedagojik alan bilgisi (TPAB) duzeylerinin yasam boyu ogrenme, oz-yeterlik duzeyleri ve hizmet ici egitim gereksinimleri acisindan incelenmesi: Mus/Bulanik ornegi) (Yayinlanmamis yuksek lisans tezi). Amasya Universitesi Sosyal Bilimler Enstitusu. Amasya, Turkiye.

*Can, S., Dogru, S., Bayir, G. (2017). Determination of pre-service classroom teachers technological pedagogical content knowledge. Journal of Education and Training Studies, 5(2). Retrieved on 14 November 2018 from http://dx.doi.org/10.11114/jets.v5i2.2083

Canbazoglu Bilici, S., Yamak, H., Kavak, N. S., Guzey, S. (2013). Technological pedagogical content knowledge self-efficacy scale (TPACK-SeS) for pre-service science teachers: construction, validation and reliability. Eurasian Journal of Education Research, 52, 3760.

*Canbolat, N.(2011). Matematik ogretmen adaylarinin teknolojik pedagojik alan bilgileri ile dusunme stilleri arasındaki iliskinin incelenmesi (Yayinlanmamis yuksek lisans tezi). Selcuk Universitesi Egitim Bilimleri Enstitusu. Konya, Turkiye.

Card, N. A. (2012). Applied meta-analysis for social science research. New York, London: Guilford.

Cetin, I. (2017). Matematik ogretmeni adaylarinin teknolojik pedagojik alan bilgisi (TPAB) duzeylerinin incelenmesi (Yayinlanmais doktora tezi). Necmettin Erbakan Universitesi Egitim Bilimleri Enstitusu. Konya, Turkiye.

*Cetin-Berber, D. Erdem, A. R. (2015). An investigation of Turkish pre-service teachers' technological, pedagogical and content knowledge. Computers, 4, 234-250. doi: 10.3390/computers4030234.

Chai, C. S., Koh, J. H. L., \& Tsai, C. C. (2013). A review of technological pedagogical content knowledge. Educational Technology \& Society, 16(2), 31-51.

Cohen, J. (1988). Statistical power analysis for the behavioural sciences (2nd ed.). Hillsdale, NJ: Erlbaum.

Cooper, H. (2010). Research synthesis and meta-analysis: A step by step approach (4th ed.). Thousand Oaks, CA: Sage.

Cuhadar, C., Bulbul, T., Ilgaz, G.(2013). Exploring of the relationship between individual innovativeness and techno-pedagogical education competencies of pre-service teachers. Elementary Education Online, 12(3), 797-807.

*Delen, K. (2016). The investigation of technological pedagogical and content knowledge level by Turkish teachers of English (Unpublished master's thesis). Cag University. Graduate School of Social Sciences. Mersin, Turkey.

*Demir Atalay, T. (2016). Turkce ogretmen adaylarinin teknolojik pedagojik alan bilgisi durumlarinin cesitli degiskenlerle iliskisi. Turkish Studies, 11(9), 247-266. DOI: http://dx.doi.org/10.7827/TurkishStudies.

Demir, T. \& Firat Durdukoca, S. (2018). Pedagojik formasyon egitimi sertifika programina devam eden ogrencilerin teknolojik pedagojik alan bilgilerinin cesitli degiskenlere gore incelenmesi. International Journal of Turkish Literature and Culture Education, 7(2), $1253-1275$. 
*Depew, R. (2015). Investigating the technological pedagogical content knowledge (TPACK) and technology leadership capacities of $k-12$ public school principals (Unpublished doctoral dissertation). Brandman University. Irvine, CA.

Dikkartin Ovez, F. T. \& Akyuz, G. (2013). Ilkogretim matematik ogretmeni adaylarinin teknolojik pedagojik alan bilgisi yapilarinin modellenmesi. Education and Science, 38(170), 321-334.

Dikmen, C.H. \& Demirer, V. (2016). Trends in studies on technological pedagogical content knowledge in Turkey between 2009 and 2013 years. Turkish Journal of Education, 5(1), 33-46.

Dincer, S. (2014). Egitim bilimlerinde uygulamali meta-analiz. Ankara. Pegem.

Ellis, P. D. (2010). The essential guide to effect size. Cambridge, UK: Cambridge University Press.

*Erdogan, A., Sahin, i. (2010). Relationship between math teacher candidates' technological pedagogical and content knowledge (TPACK) and achievement levels. Procedia Social and Behavioral Sciences, 2, 2707-2711.

Glass, G.V. (1976). Primary, secondary and meta-analysis of research. Educational Researcher, 5, 3-8.

Gomleksiz M. N. \& Fidan E .K. (2013). Sinif ogretmeni adaylarinin teknolojik pedagojik icerik bilgisi oz-yeterliklerine iliskin algi duzeyleri. Inonu University Journal of Education Faculty, 14(1), 87-113.

Graham, C. R., Burgoyne, N., Cantrell, P., Smith, L., St. Clair, L., Harris, R. (2009). TPACK development in science teaching: Measuring the TPACK confidence of inservice science teachers. TechTrends, 53(5), 70-79.

Gravel, R. J. (2014). The effects of pre-kindergarten through twelfth grade in-service teachers' participation in a professional development course aligned with the TPACK framework (Unpublished doctoral dissertation). Northern Illinois University. DeKalb, IL.

Gliner A. J., Morgan A. G., Leech L. N. (2015). Uygulamada araştirma yontemleri desen ve analizi butunlestiren yaklasim (Trans. Ed: S. Turan). Ankara: Nobel.

*Gundogmus, N. (2013). Ogretmen adaylarinin teknolojik pedagojik alan bilgileri ile ogrenme stratejileri arasındaki iliskinin incelenmesi (Yayinlanmamis yuksek lisans tezi). Necmettin Erbakan Universitesi Egitim Bilimleri Enstitusu. Konya, Turkiye.

Gur, H. \& Karamete, A. (2015). A short review of TPACK for teacher education. Academic Journals, 10(7), 777-789.

Haciomeroglu, G., Sahin, C., Arcagok, S. (2014). Turkish adaptation of preservice teachers' technological pedagogical content knowledge assessment scale. Theory and Practice in Education (Egitimde Kuram ve Uygulama), 10(2), 297-315.

Higgins, J. P. T, Thompson, S. G., Deeks, J. J., \& Altman, D. G. (2003). Measuring inconsistency in meta-analyses. $B M J, 6(327), 557-560$.

Holland, D. D. (2014). Technological, pedagogical and content knowledge (TPACK) competencies of preservice teachers at a small rural university (Unpublished doctoral dissertation). Arizona Northcentral University. Scottsdale, AZ, United States.

Isiguzel, B. (2014). Almanca ogretmen adaylarinin teknopedagojik egitime yonelik yeterlik duzeylerinin incelenmesi. The Journal of International Social Research, 7(34), 768-778. 
Jang S.-J., Tsai M. F. (2013). Exploring the TPACK of Taiwanese secondary school science teachers using a new contextualized TPACK Model. Australasian Journal of Educational Technology, 29(4), 566-580.

Kabakci Yurdakul I. (2011). Ogretmen adaylarinin teknopedagojik egitim yeterliklerinin bilgi ve iletisim teknolojileri kullanimlari acisindan incelenmesi. Hacettepe Universitesi Egitim Fakultesi Dergisi, 40, 397-408.

Kabakci Yurdakul I., Odabasi, F. H., Kılıcer, K., Coklar, A.N., Birinci, G., Kurt, A. A. (2012). The development, validity and reliability of TPACK-deep: A technological pedagogical content knowledge scale. Computer and Education, 58(3), 964-977.

Kabakci Yurdakul, I. (Ed.), Odabasi, F. (2013). Teknopedagojik egitime dayali ogretim teknolojileri ve materyal tasarimi. Ankara: Ani.

*Kabaran, H. (2016). Ogretim elemanlarinin teknolojik pedagojik alan bilgileri (TPAB) ile ogretme stilleri arasındaki iliskinin incelenmesi (Yayinlanmamis yuksek lisans tezi). Mugla Sitki Kocman Universitesi Egitim Bilimleri Enstitusu. Mugla, Turkiye.

Kaleli Y.G. (2015). Turkiye'deki teknolojik pedagojik alan bilgisi calismalarinin analizi: Bir metasentez calismasi. Egitim ve Bilim, 40(178), 103-122.

*Karaca, F. (2015). An investigation of pre-service teachers' technological pedagogical content knowledge based on a variety characteristics. International Journal of Higher Education, 4(4), 128-136.

Karademir, E. (2015). Egitsel internet kullanimi ile teknolojik pedagojik alan bilgisi ve egitim teknolojilerine yonelik tutum arasındaki iliski: ogretmen adayları ornegi. International Periodical for the Languages, Literature and History of Turkish or Turkic, 10(15), 519-534.

Karadeniz, S., Vatanartiran, S. (2015). Primary school teachers' technological pedagogical content knowledge. Elementary Education Online, 14(3), 1017-1028.

*Karatas, A. (2014). Lise ogretmenlerinin FATIH Projesi'ni Uygulamaya yonelik teknolojik pedagojik alan bilgisi yeterliklerinin incelenmesi: Adiyaman ornegi (Yayinlanmamis yuksek lisans tezi). Sakarya Universitesi Egitim Bilimleri Enstitusu. Sakarya, Turkiye.

Karatas, I., Piskin-Tunc, M., Demiray, E. ve Yilmaz, N. (2016). Ogretmen adaylarinin matematik ogretiminde teknolojik pedagojik alan bilgilerinin gelistirilmesi. Abant lzzet Baysal Universitesi Egitim Fakultesi Dergisi, 16(2), 512-533.

*Kartal, T., Afacan, O. (2017). Examining Turkish pre-service science teachers' technological pedagogical content knowledge (TPACK) based on demographic variables. Journal of Turkish Science Education, 14(1), 1-22.

Kaya, Z., Ozdemir, T. Y., Emre, I. \& Kaya, O. N. (2011). Exploring preservice information technology teachers' perception of self-efficacy in web-technological pedagogical content knowledge. Paper presented at the 6th International Advanced Technologies Symposium (IATS'11). Elazig, Turkey.

Kaya, S. \& Dag, F. (2013). Sinif ogretmenlerine yonelik teknolojik pedagojik icerik bilgisi olcegi'nin Turkce'ye uyarlanmasi. Educational Sciences in Theory and Practice, 13(1), 291-306.

Kaya, Z., Kaya, O. N. \& Emre, G. (2013). Teknolojik pedagojik alan bilgisi (TPAB) olçegi'nin Turkçe'ye uyarlanmasi. Educational Sciences: in Theory and Practice, 13(4). 2355-2377. 
Kaya, Z. (2014). Harmanlanmis ogrenmenin fen bilgisi ogretmen adaylarinin kuresel isinma konusundaki teknolojik pedagojik alan bilgisi ve sinif ici ogretim becerilerinin gelistirilmesi uzerine etkisi (Yayinlanmamis doktora tezi). Firat Universitesi Egitim Bilimleri Enstitusu. Elazig, Turkiye.

Kazu, I. Y., Erten, P. (2014). Teachers' technological pedagogical content knowledge selfefficacies. Journal of Education and Training Studies, 2(2), 126-144. DOI: https://doi.org/10.11114/jets.v2i2.261

Kiray, A. S. (2016). Development of a TPACK self-efficacy scale for preservice science teachers. International Journal of Research in Education and Science, 2(2), 527-541.

*Kiylik, D. (2016). Sinif ogretmeni adaylarinin teknolojik pedagojik alan bilgisi (TPAB) seviyelerinin cesitli degiskenlere gore incelenmesi (Yayinlanmamis yuksek lisans tezi). Yuzuncu Yil Universitesi Egitim Bilimleri Enstitusu. Van, Turkiye.

Koehler, M. J., Mishra, P. (2005). What happens when teachers design educational technology? The development of technological pedagogical content knowledge. Journal of Educational Computing Research, 32(2), 131-152.

Koehler, M. J., Mishra, P. (2008). Introducing technological pedagogical knowledge. In AACTE (Eds.). The handbook of technological pedagogical content knowledge for educators (p.14). New York: Routledge.

Koehler, M. J., \& Mishra, P. (2009). What is technological pedagogical content knowledge? Contemporary Issues in Technology and Teacher Education, 9(1), 60-70.

Koh, J.H.L and Sing, C.C. (2011). Modeling pre-service teachers' technological pedagogical content knowledge (tpack) perceptions: the influence of demographic factors and TPACK constructs. Paper presented at ASCILITE Australian Society for Computers in Learning in Tertiary Education Annual Conference. Australia.

Kula, A. (2015). Ogretmen adaylarinin teknolojik pedagojik alan bilgisi (Tpab) yeterliliklerinin incelenmesi: Bartin Universitesi Ornegi. Akademik Sosyal Arastirmalar Dergisi, 3(12), 395-412.

Kurt, A. A. \& Kabakci Yurdakul, I. (Ed.) (2013). Teknopedagojik egitime dayali ogretim teknolojileri ve materyal tasarimi. 1. Ed. Ankara: Anı Press.

Leech, N. L., Onwuegbuzie, A. J. (2002, November). Nonparametric statistics. Annual meeting of the mid-south educational research association. Chattanooga, TN.

Lipsey, M.W., \& Wilson, D.B. (2001). Practical meta-analysis. Thousand Oaks, CA: Sage.

Miles, M.B. \& Huberman, AM. (1994). Qualitative data analysis. Thousand Oaks, CA: Sage.

Millen, R. (2015). Closing the gap between technological and best practice innovations: teachers' perceived technological pedagogical content knowledge and self-efficacy towards differentiated instruction (Unpublished doctoral dissertation). Johnson \& Wales University. Providence, RI.

*Mutluoglu, A. (2012). Ilkogretim matematik ogretmenlerinin ogretim stil tercihlerine gore teknolojik pedagojik alan bilgilerinin incelenmesi (Yayinlanmamis yuksek lisans tezi). Necmettin Erbakan Universitesi Egitim Bilimleri Enstitusu. Konya, Turkiye.

North, A. S. \& Noyes, J. M. (2002). Gender influences on children's computer attitudes and cognitions. Computers in Human Behavior, 18(2), 135-150. 
${ }^{*} \mathrm{Oz}, \mathrm{H}$. (2015). Assessing pre-service English as a foreign language teachers' technological pedagogical content knowledge. International Education Studies, 8(5), 119-130.

Ozaydinlik, K. (2014). Toplumsal cinsiyet temelinde Turkiye'de kadin ve egitim. Sosyal Politika Calismalari Dergisi, 33, 93-112. DOI: http://dx.doi.org/10.21560/spcd.03093.

*Ozturk, E. (2013). Sinif ogretmenlerinin teknolojik pedagojik alan bilgilerinin bazi degiskenler acisindan degerlendirilmesi. Usak Universitesi Sosyal Bilimler Dergisi, 6(2), 223-228.

Pamuk, S., Ulken, A. \& Dilek, N. S. (2012). Ogretmen adaylarinin ogretimde teknoloji kullanim yeterliliklerinin teknolojik pedagojik içerik bilgisi kuramsal perspektifinden incelenmesi. Mustafa Kemal Universitesi Sosyal Bilimler Enstitusu Dergisi, 9(17), 415-438.

Pamuk, S., Ergun, M., Cakir, R., Yilmaz, H.B., Ayas C. (2015). Exploring relationships among TPACK components and development of the TPACK instrument. Educ. Inf. Technol., 20(2015), 241-263. DOI 10.1007/s10639-013-9278-4.

Price G. F., Wright V. H., Rice M. L. (2014). Determining the impact of an integrated triadic model on TPACK development in preservice teachers. Journal of Digital Learning in Teacher Education, 30(4), 139-149. DOI: 10.1080/21532974.2014.927250.

*Roig-Vila R., Mengual-Andrés S., Quinto-Medrano P. (2015). Primary teachers' technological, pedagogical and content knowledge. Media Education Research Journal, 45(23), 151159. DOI http://dx.doi.org/10.3916/C45-2015-16.

*Sad S. N., Acikgul, K., Delican, K. (2015). Senior pre-service teachers' senses of efficacy on their technological pedagogical content knowledge (TPACK). Journal of Theoretical Educational Science, 8(2), 204-235. DOI: http://dx.doi.org/10.5578/keg.9480.

Sahin, i. (2011). Development of survey of technological pedagogical and content knowledge (TPACK). The Turkish Online Journal of Educational Technology, 10(1), 97-105.

Sainz, M. \& Saez, M. L. (2010). Gender differences in computer attitude and the choice of technology related occupations in a sample of secondary students in Spain. Computers \& Education, 54(2), 578-587.

*Saka Ozturk, H. (2017). Ogretmenlerin tekno-pedagojik alan bilgisi (TPAB) duzeyleri, ogrencilerin oz-yeterlikleri ve akademik basarilari arasindaki iliskilerin incelenmesi (Yayinlanmamis yuksek lisans tezi). Necmettin Erbakan Universitesi Egitim Bilimleri Enstitusu. Konya, Turkiye.

Sancar Tokmak H., Yavuz Konokman G., Yanpar Yelken T. (2013). Mersin Universitesi okul oncesi ogretmen adaylarinin teknolojik pedagojik alan bilgisi (tpab) ozguven algilarinin incelenmesi. Ahi Evran Universitesi Kirsehir Egitim Fakultesi Dergisi, 14(1), 35-51.

Schmidt, D., Baran, E., Thompson, A., Mishra, P., Koehler, M.J., \& Shin, T. (2009a). Technological pedagogical content knowledge (TPACK): The development and validation of an assessment instrument for preservice teachers. Journal of Research on Technology in Education, 42(2), 123-149.

Tuncer, M., Dikmen, M. (2018). Cinsiyetin tekno-pedagojik alan bilgisi uzerindeki etkisinin meta-analiz yontemiyle arastirilmasi. Firat Universitesi Sosyal Bilimler Dergisi, 28(1), 8592.

*Turgut, T. (2017). Sosyal bilgiler ogretmenlerinin teknolojik pedagojik alan bilgisi yeterlilikleri: Karabuk ili ornegi (Yayinlanmamis yuksek lisans tezi). Karabuk Universitesi Sosyal Bilimler Enstitusu. Karabuk, Turkiye. 
*Unlu, I., Kaskaya, A., Coskun, M. K. (2017). Sosyal bilgiler ogretmen adaylarinin teknolojik pedagojik alan bilgisi yeterliklerinin cesitli degiskenlere gore incelenmesi. Erzincan Universitesi Egitim Fakultesi Dergisi, 19(1), 1-24. DOI: 10.17556/erziefd.295611.

Viechtbauer, W. (2017). Metafor: Meta-analysis package for R. R package version 2.0-0 [Data files].https://cran.r-project.org/web/packages/metafor/index.

Wright, B. \& Akgunduz, D. (2018). The relationship between technological pedagogical content knowledge (TPACK) self-efficacy belief levels and the usage of Web 2.0 applications of pre-service science teachers. World Journal on Educational Technology: Current Issues. 10(1), 70-87.

Yanpar Yelken T. (2012). Ogretim teknolojileri ve materyal tasarimi (11.Ed.). Ankara: Ani.

Yanpar Yelken T., Sancar Tokmak H., Ozgelen, S \& Incikapi, L. (2013). Teknolojik- pedagojikalan bilgisi (tpab) cercevesi ve bu cercevenin Milli Egitim Bakanligi fen ve matematik egitimi programindaki yeri. T. Y.Yelken, H. S. Tokmak, S. Ozgelen and L. Incikapi (Eds.) Fen ve matematik egitiminde teknolojik pedagojik alan bilgisi temelli ogretim tasarimlari (pp.2-10). Ankara: Ani.

Yavuz Konokman, G., Yanpar Yelken, T., Sancar Tokmak, H. (2013). Sinif ogretmeni adaylarinin TPAB'lerine iliskin algilarinin cesitli degiskenlere gore incelenmesi: Mersin Universitesi ornegi. Kastamonu Universitesi Egitim Fakultesi Dergisi, 21(2), 666-684.

Correspondence: Tugba Yanpar Yelken, Professor, Department of Educational Sciences, Faculty of Education, Mersin University, Ciftlikkoy Campus, Yenisehir, Mersin, Turkey 